\title{
ERRATA
}

\section{Microvascular Composite Tissue Transfer for the Management of Type IIIB and IIIC Fractures of the Distal Leg and Compound Foot Fractures}

\author{
Ramzi Musharrafieh, ${ }^{1}$ Osmar Osmani, ${ }^{1}$ Said Saghieh, ${ }^{1}$ Bassem Elhassan, ${ }^{1}$ \\ and Bishara Atiyeh ${ }^{1}$
}

The publisher regrets a typographical error in the name spelled "Bassem El-Hassan" in the above article in Journal of Reconstructive Microsurgery, Volume 15, Number 7, 1999, p. 501. The corrected spelling appears above.

${ }^{1}$ Department of Orthopaedic Surgery, American University of Beirut Medical Center, Beirut, Lebanon.

Address for correspondence and reprint requests: Dr. Ramzi Musharrafieh, c/o American University of Beirut, New York Office, 850 Third Avenue, 18 Floor, New York, NY 10022.
J Reconstr Microsurg 2007;23:119. Copyright (C) 2007 by Thieme Medical Publishers, Inc., 333 Seventh Avenue, New York, NY 10001, USA. Tel: $+1(212)$ 584-4662.

DOI 10.1055/s-2007-971080. ISSN 0743-684X. 